ECOLOGICA, Vol. 28, No 104 (2021), 573-580

https://doi.org/10.18485/ecologica.2021.28.104.12

Originalni naučni rad

UDC: 338.48-6:502/504]:[616.98:578.834]

311.21

\title{
Analiza stavova javnosti o ekoturizmu i predikcija njegovog daljeg razvoja nakon pandemije COVID-19
}

\section{Analysis of public attitudes on ecotourism and predicting its further development after the pandemic COVID 19}

\author{
Dragan Milošević ${ }^{*}$, Dejan llić ${ }^{2}$, Jovanka Popović3 \\ ${ }^{1,3}$ Fakultet za menadžment, Njegoševa 1a, Sremski Karlovci, Univerzitet Union - Nikola Tesla, Beograd, Srbija / \\ Faculty of Management, Njegoševa 1a, Sremski Karlovci, University Union - Nikola Tesla, Belgrade, Serbia \\ ${ }^{2}$ Fakultet za poslovne studije i pravo, Jurija Gagarina 149a, Univerzitet Union - Nikola Tesla, Beograd, Srbija / \\ Faculty of Business Studies and Law, Jurija Gagarina 149a, University Union - Nikola Tesla, Belgrade, Serbia \\ *Autor za prepisku / Corresponding author
}

Rad primljen / Received: 09.08.2021, Rad prihvaćen / Accepted: 02.11.2021.

Sažetak: Ekoturizam se zasniva na sticanju pozitivnih iskustava turista boravkom na destinacijama u prirodi i upoznavanjem sa autentičnostima lokalnih kultura, istorijskim nasleđem i običajima. Od saradnje turista i lokalne zajednice treba da svi ostvare koristi sa minimalnim negativnim uticajem na lokalnu prirodno okruženje i lokalno stanovništvo. U radu se istražuju stavovi javnog mnjenja o ekoturizmu. Prema sprovedenom istraživanju više od pola ispitanika je čula za ekološki turizam. Polovina ispitanika veruje da je najznačajniji efekat ekoturizma očuvanje prirode. Kao najznačajniji negativan uticaj koji ostvaruje ekoturizam ispitanici su naveli da je to pritisak na lokalnu infrastrukturu. Nakon upoznavanja sa principima ekoturizma 97,1\% ispitanika je navelo da je to pozitivan koncept koji ostvaruje više pozitivnih nego negativnih efekata. Ekoturizam iz godine u godinu beleži blagi rast do pojave pandemije COVID-19. Sa pojavom pandemije, turističko tržište u svetu beleži pad do $78 \%$. Ovaj pad će zahtevati sprovođenje radikalnih strukturnih promena i određeni vremenski period potreban da se turistička industrija oporavi. Nakon prestanka pandemije, zbog značaja koji ima ekoturizam za zdravlje ljudi, očekuje se njegov potpuni oporavak i rast.

Ključne reči: ekoturizam, globalni trendovi u turizmu, održivi turizam, zeleni turizam, javno mnjenje, pandemija COVID-19.

\begin{abstract}
Ecotourism is based on gaining positive experiences of tourists by staying in destinations in nature and learning about the authenticity of local cultures, historical heritage and customs. From co-operation between tourists and the local community, everyone should benefit with minimal negative impact on the local natural environment and locals. The paper explores public opinion views on ecotourism. According to the survey, more than half of respondents heard about ecological tourism. Half of respondents believe the most significant effect of ecotourism is the preservation of nature. As the most significant negative impact generated by ecotourism, respondents said it was a pressure on local infrastructure. After introducing the principles of ecotourism, $97.1 \%$ of respondents said it was a positive concept that achieved more positive than negative effects. Ecotourism has seen a slight increase year after year until the outbreak of the COVID-19 pandemic (on 19. December). With the advent of pandemics, the world's tourism market is down to $78 \%$. This decline will require radical structural changes and a certain period of time it takes for the tourism industry to recover. After the cessation of the pandemic, due to the importance of ecotourism to human health, its full recovery and growth is expected.
\end{abstract}

Keywords: ecotourism, global trends in tourism, sustainable tourism, green tourism, public opinion, COVID-19 pandemic.

10rcid.org/0000-0002-5979-2562, e-mail: dmilosevic321@gmail.com,dragan.milosevic@famns.edu.rs

2orcid.org/0000-0001-8966-9955,e-mail:dejan.ilic@fpsp.edu.rs

${ }^{3}$ orcid.org/0000-0003-0263-0295, e-mail: jovanka.popovic@famns.edu.rs 


\section{UVOD / INTRODUCTION}

Koliko god bili svesni da nam primena tehnologije omogućava blagodeti savremene civilizacije, to raste i svest da prirodna sredina predstavlja uslov za opstanak ljudske civilizacije. Savremeni čovek želi da ima sav konfor koje nudi civilizacija, ali takođe želi da i aktivno boravi u nezagađenoj prirodi. Do sada, gde god je čovek pravio svoja savremena staništa, ostavljao je za sobom trajne negativne posledice po prirodnu sredinu. Bilo da se radi o primeni tehnologije, zagađenju ili nekontrolisanoj upotrebi resursa. Savremeni čovek ne vodi dovoljno računa o posledicama koje njegove aktivnosti ostavljaju po prirodnu sredinu.

Motivi savremenih ljudi koji koriste dobrobiti aktivnog boravka u prirodi mogu biti različiti, od smanjenja stresa, do poboljšanja kondicije ili opšteg zdravstvenog stanja. Ono što povezuje ove motive je da se zasnivaju na potrebi da se kroz razne aktivnosti ljudi, na određeno vreme, relaksiraju u prirodnom okruženju. Potreba savremenog čoveka da se vrati i provodi vreme u nezagađenoj prirodi, čini probleme očuvanja prirode ključnim problemima razvoja i održanja ljudske civilizacije. Održivi razvoj je nemoguće zamisliti bez adekvatnog odnosa čoveka prema svom prirodnom okruženju.

Predviđa se da će segment ekoturizma u budućnosti doživeti značajan rast nakon pandemije COVID 19. Iz navedenog razloga, potrebno je razumeti viđenje i stavove javnog mnjenja o ekoturizmu pre i nakon edukacije. Ovo istraživanje je značajno i za formiranje propagandnih poruka koje će turističke organizacije plasirati sa namerom da privuku turiste.

U razvijenim zemljama sve više je reklama koje nude u turističkoj ponudi ekoturizam, „zeleno putovanje“, „održivo odmaralište“, „ekološke ture“ i sl. Pojmovi kao što je zeleni ili održivi turizam, često se koriste pogrešno u propagandne svrhe. lako pojmovi kao što su eko, zeleni ili održivi turizam deluju isto, među njima ima sličnosti ali i razlika. Razlike su u određenim principima i njihovoj primeni.

Turizam koji nije ekološki kontrolisan, može naneti velike i često nepopravljive štete, upravo onim stvarima u prirodi, radi kojih turisti i dolaze. Kumar (2020) navodi da je „... važno da pazimo na planetu jer ako nam nije stalo do mesta, neće biti ni nama mesta za posetu“.

Zeleni turizam se prema (Kumar, 2020) koristi kao termin još od osamdesetih godina prošlog veka za hotele koji imaju neke ekološki prihvatljive aktivnosti ali koji nisu dostigli nivo ekološke održivosti. Tokom vremena sve više turističkih objekata uvodi neku formu ekološke održivosti, koristeći programe reciklaže, upotreba ekološki prihvatljivih sredstava za čišćenje, očuvanje voda, smanjenje buke i sl. Ovakve aktivnosti navode se u turističkim propagandnim materijalima, sa ciljem privlačenja turista sa višim nivoom ekološke svesti. To su turisti koji očekuju određeni nivo komfora u očuvanoj prirodnoj sredini, mesta gde bio-diverzitet nije u velikoj meri poremećen od strane ljudske civilizacije. Efekti koje ostvaruje zeleni turizam, ako se primenjuju principi održivog razvoja, su multiplikujući i veoma značajni za ekonomiju na duži rok (Janković i dr., 2020)

Ekoturizam (ili ekološki turizam) je prema definiciji koju je postavio eminentni The International Ecotourism Society (TIES n.d.) čine "odgovorna putovanje u prirodna područija koja čuvaju životnu sredinu, i podržavaju dobrobit lokalnog stanovništva, uključujući obaveštenost i obrazovanje“. Pri tome obrazovanje se odnosi na kako na domaćine, tako i na goste. Ekoturizam treba da pruži zaštitu i lokalnim zajednicama, i životnoj sredini. Isti izvor (TIES) navodi principe preko kojih treba razvijati ekoturizam:

- Smanjiti fizičke, socijalne, biohejviorističke i psihološke uticaje na destinacije (životnu sredinu i lokalno stanovništvo).

- Izgraditi ekološku i kulturnu svest, u cilju poštovanja lokalnih zajednica.

- Pružiti pozitivna iskustva posetiocima i domaćinima.

- Obezbediti direktne finansijske koristi za očuvanje prirodne sredine destinacija i autentičnost lokalnih zajednica.

- Stvoriti finansijske koristi za lokalno stanovništvo i za njihovu privatnu industriju.

- Posetiocima pružiti nezaboravna iskustva, koja pomažu u podizanju svesti o političkoj, ekološkoj i socijalnoj klimi, zemalja domaćina.

- Dizajnirati, konstruisati i upravljati, turističkim objektima sa malim uticajem na destinacije.

- Prepoznati prava i duhovna verovanja lokalnog starosedelačkog naroda. Razvijati saradnju i partnerstvo sa njima.

Turizam koji primenjuje principe održivog razvoja je prema United Nations World Tourism Organization (UNWTO n.d.) „Turizam koji u potpunosti uzima u obzir trenutne i buduće ekonomske, socijalne i ekološke uticaje, obraćajući se potrebama posetilaca, industrije, životne sredine i zajednice domaćina“. Ovi principi očekuju se da se primene na sve vidove masovnog turizma. Na sve njegove segmente, kao što je i ekološki turizam. Isti izvor navodi, da održivi razvoj u turizmu počiva na primeni sledeća tri principa:

- Treba optimalno iskoristiti sve resurse životne sredine, sa ciljem očuvanja prirodnog nasleđa i bio-diverziteta.

- Potrebno je poštovati socio-kulturološke autentičnost i kulturološko nasleđe zajednica domaćina. 
- Neophodno je osigurati dugoročno održivo ekonomsko poslovanje, što podrazumeva pružanje društvene i ekonomske koristi, pravično raspoređene svim zainteresovanim stranama, omogućavajući lokalnom stanovništvu stabilno zapošljavanje, socijalne usluge, dohodak a sve u cilju smanjenja siromaštva. Siromaštvo je jedan od glavnih motiva migracije lokalnog stanovništva ka urbanim sredinama.

Ekoturizam i održivi razvoj (eng. Sustainable Development) su slični koncepti koji se razlikuju u opsegu aktivnosti koje zahtevaju u primeni. Održivi razvoj predstavlja širi fokus aktivnosti delovanja, nego što ga zahteva ekoturizam (Slika 1). Održivi razvoj u sebi sadrži osim razvoja ekoturizma i regionalni razvoj. Razvoj ekoturizma ima svoje dimenzije razvoja, koje se odnose na:

- socijalni (Social) razvoj,

- ekonomski (Economic) razvoj,

- ekološki (Environment) razvoj.

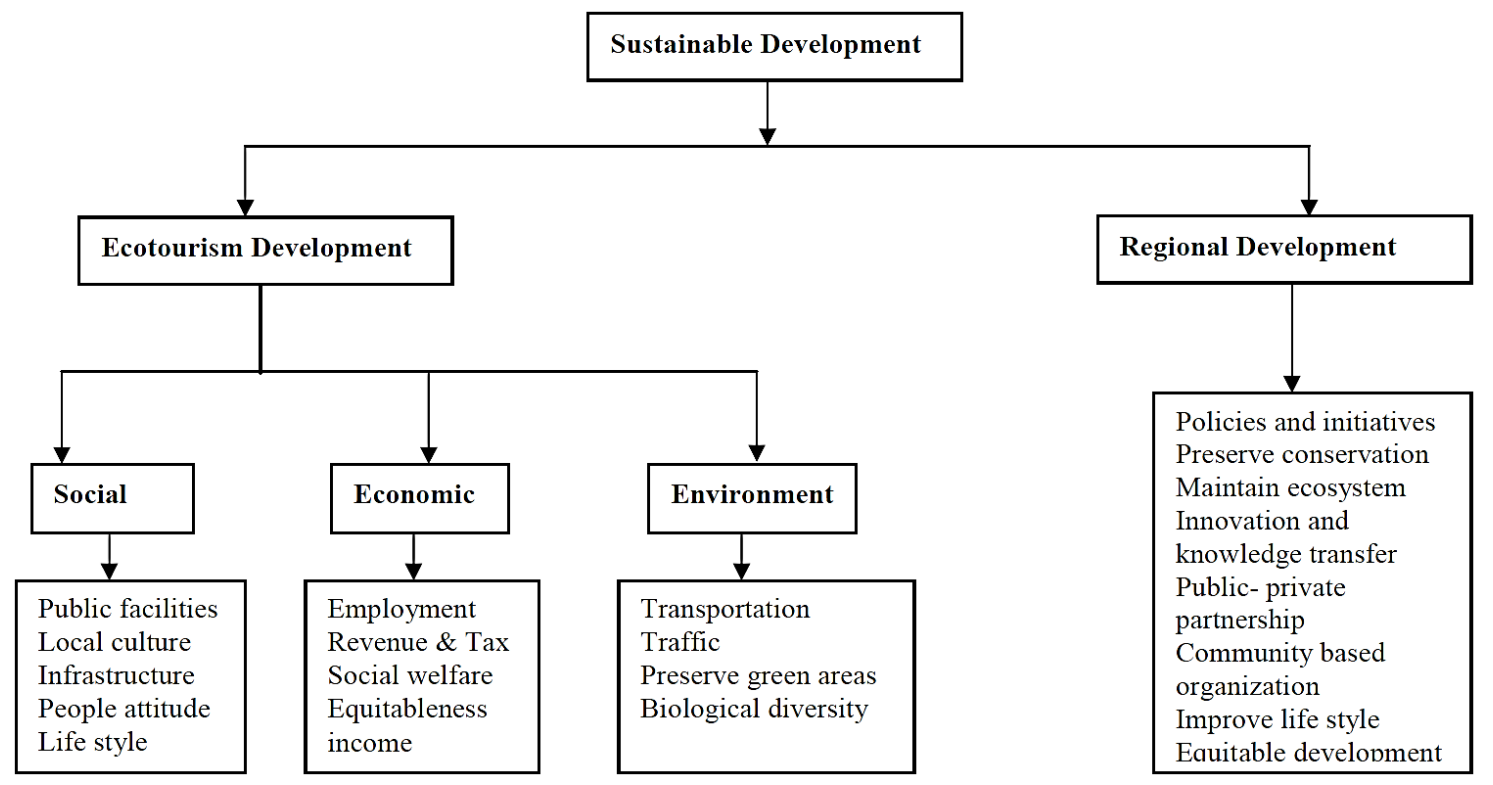

Slika 1. Održivi razvoj .

Figure 1. Sustainable development

Izvor / Source: Bhuiyan et al. (2012)

Održivi razvoj za razliku od ekoturizma, odnosi se ne samo na ruralna već i na urbana naselja. Velike urbane sredine su takođe atraktivne turističke destinacije, koje predstavljaju značajan deo masovne turističke ponude. Urbana naselja se suočavaju sa ekološkim problemima, kao što su upravljanja vodama, recikliranja otpada, upotreba energije, očuvanje kulturnog nasleđa lokalnih zajednica, razne vrste zagađenja itd. Održivi razvoj, za razliku od ekoturizma, insistira da lokalnom stanovništvu, bude pošteno nadoknađene prodaja (lokalnih) proizvoda i zarade za njihovo angažovanje. Sve je u nameri da se zaštiti lokalno stanovništvo, njegova dobrobit kao i njegovo prirodno i kulturno nasleđe (Kumar, 2020; Mladenović, Bojičić, 2020). Ono treba da primenjuje principe održivog razvoja, jer je njihov uticaj veliki na regionalni i globalni ekosistem.

Efekti koje ostvaruje zeleni i ekoturizam, ako se na njih primenjuju principi održivog razvoja, su multiplikujući i veoma značajni za ekonomiju turističkih destinacija na duži rok (Janković, Bojičić, 2020). Da bi se sproveo razvoj turizma, na ovim principima, po- trebna je dobra informisanost ali i jaka podrška svih zainteresovanih strana. To je jedan kontinuiran proces koji je potrebno stalno pratiti i razvijati. Za potrebe praćenja uticaja turizma na lokalnu sredinu turističke destinacije osnovana je organizacija pri Ujedinjenim nacijama World Tourism Organization International Network of Sustainable Tourism Observatories (INSTO n.d.). Misija ove organizacije, je da prati ekonomske, ekološke i društvene uticaje koje ima turizam na destinacije.

Cilj ovog rada je utvrđivanje stavova javnog mnjenja o ekoturizmu, pre i nakon upoznavanja sa njegovim principima.

\section{MATERIJALI I METODE / MATERIALS AND METHODS}

Ovo istraživanje je sprovedeno deskriptivnom metodom i uporednom analizom, a takođe statističkom obradom podataka. Kao izvori podataka korišćene su referentne globalne organizacije i eksperti, koji prate problematiku životne sredine i ekoturizma. 


\section{REZULTATI I DISKUSIJA /} RESULTS AND DISCUSSION

\subsection{Segmentacija turističkog tržišta I Tourism market segmentation}

Turističko tržište (Tourism Market) može se podeliti u nekoliko segmenata, kao što je prikazano na slici 2. Segmenti turističkog tržišta su: kulturni turizam (Cultural Tourism), seoski turizam (Rural Tourism), turizam boravka u prirodi (Nature Tourism), turizam na plaži (Sun and Beach Tourism), poslovna putovanja (Business Travel) i turizam radi dobrog zdravlja i kondicije (Fitness-Wellness and Health Tourism). Jedan deo turizma boravka u prirodi čine: ekoturizam i avanturistički turizam.

U ekoturizmu turisti očekuju da na svojim turama dožive jedinstvena prijatna iskustva u prirodi i susretima s lokalnim stanovništvom. Ovaj vid turizma u prirodi se razlikuje od avanturističkog turizma (Slika 2) po nivou uzbuđenja i rizika koji nose sa sobom. Ekoturizam je namenjen širokoj populaciji turista, posmatrano po godinama i zdravstvenim mogućnostima.

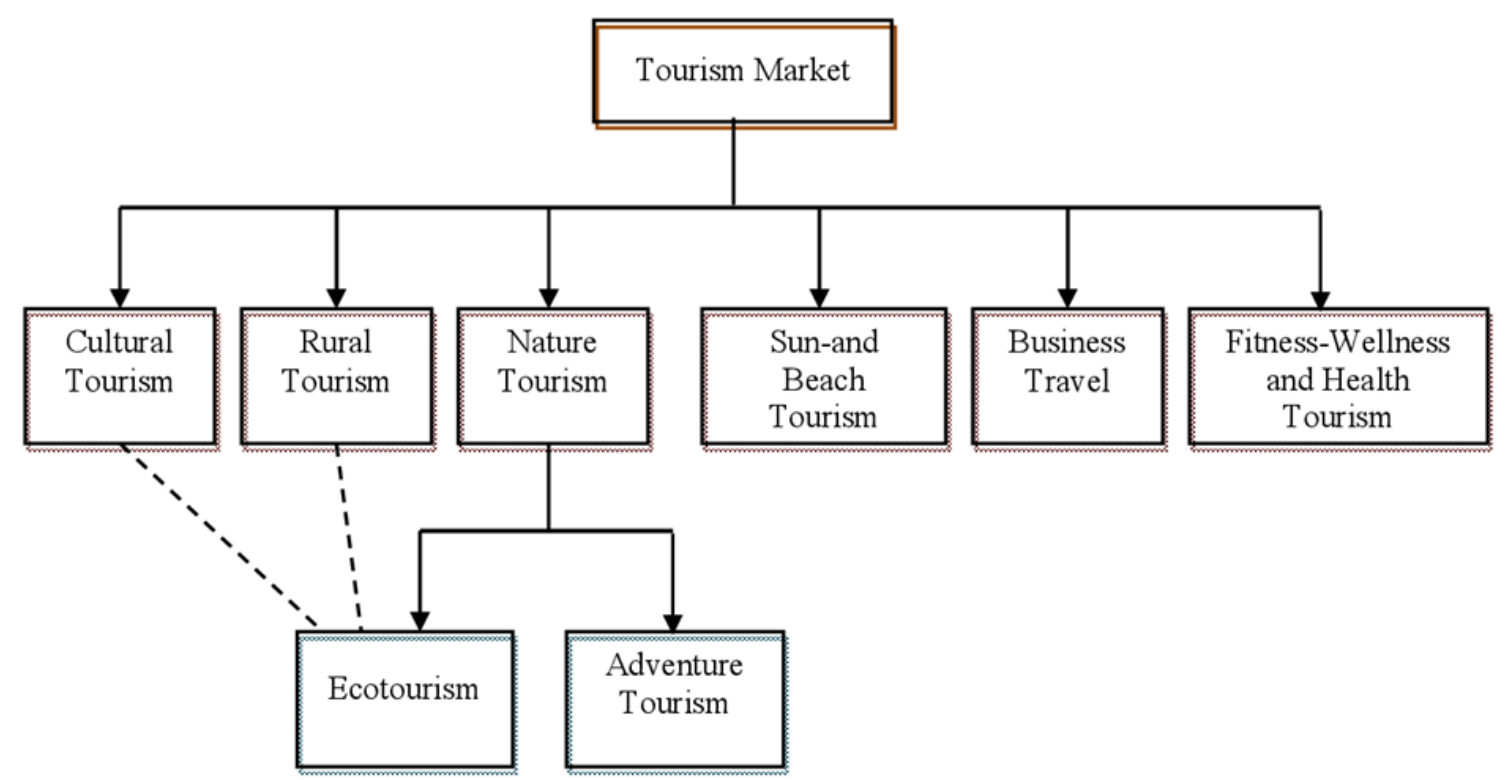

Slika 2. Segmentacija turističkog tržišta

Figure 2. Segmentation of the tourist market. Izvor / Source: WTO, (Strasdas, 2001)

\subsection{Stavovi javnosti o ekoturizmu / Public attitudes about ecotourism}

Pre pandemije COVID-19 sprovedeno je istraživanje (Globalecotourism1, 2016) o stavovima javnog mnjenja o ekoturizmu, pre i nakon upoznavanja učesnika istraživanja s njegovim principima. Dobijeni rezultati prikazani su grafički. U istraživanju je $57,1 \%$ učesnika navelo da je čulo za ekoturizam. Ovaj podatak ukazuje da nije urađeno dovoljno na promovisanju i upoznavanju vrednosti ekoturizma. Jedan deo istraživanja je bio vezan za utvrđivanje stavova ispitanika, o tome šta su pozitivni a šta negativni efekti ekoturizma.

Dijagram 1 pokazuje koji su pozitivni uticaji ekoturizma, prema mišljenju ispitanika:

- Polovina $(50 \%)$ učesnika veruje da je očuvanje prirode (Nature Conservation), najkorisniji efekat koji ostvaruje ekoturizam.
- Kreiranje radnih mesta i ostvarivanje ekonomske koristi (Creating jobs and additional income) je na drugom mestu i to je mišljenje $16,7 \%$ ispitanika.

- Podizanje nivoa obrazovanja i aktivizma među putnicima (eng. Increse the level of education and activism among travellers) deli treće mesto sa

- osnaživanjem mogućnosti lokalnih zajednica (eng. Potential to empower local communities), oba po $14,3 \%$ odgovora.

- Ekonomska raznolikost privrede (Economic diversity) sa $4,7 \%$ odgovora je na poslednjem mestu, po zastupljenosti stavova u istraživanju. 


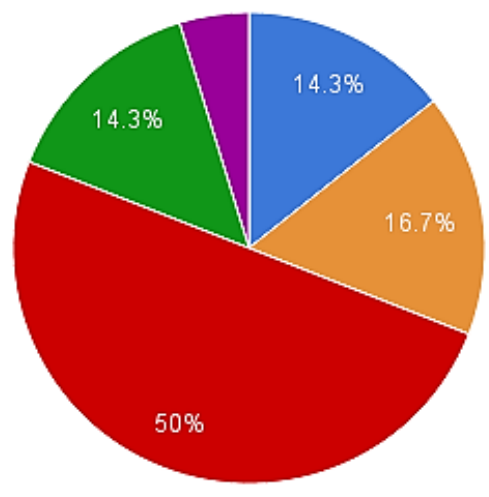

Potential to empower local communities

Creation of jobs and additional income

Nature

Conservation

Increase the level of education and activism among travellers

Economic Diversity

Dijagram 1. Stavovi i mišljenja ispitanika o pozitivnom uticaju ekoturizm

Graph 1. Respondents' views and opinions on the positive impact of ecotourism.

Izvor / Source: Globalecotourism 1, 2016.

Pored pozitivnih, ekoturizam ima i značajne negativne posledice. Učesnici istraživanja su kao negativne efekte ekoturizma naveli sledeće (dijagram 2):

- Pritisak ljudi na lokalnu infrastrukturu (population pressures), po mišljenju $28,2 \%$ ispitanika.

- Zagađenje, buku, otpad, ugrožavanje voda itd. (pollution: noise, waste, visual etc.) je navelo $23,1 \%$ ispitanika.

- Ostvarena dobit ne donosi (dovoljno) koristi lokalnoj zajednici (profits are not benefiting local community) je stav $20,5 \%$ ispitanika.

- uznemiravanje stanovništva (population disturbance) je navelo $17,9 \%$ ispitanika.
- konkurencija za prirodne resurse (competition for natural resources), prema mišljenju $10,3 \%$ ispitanika.

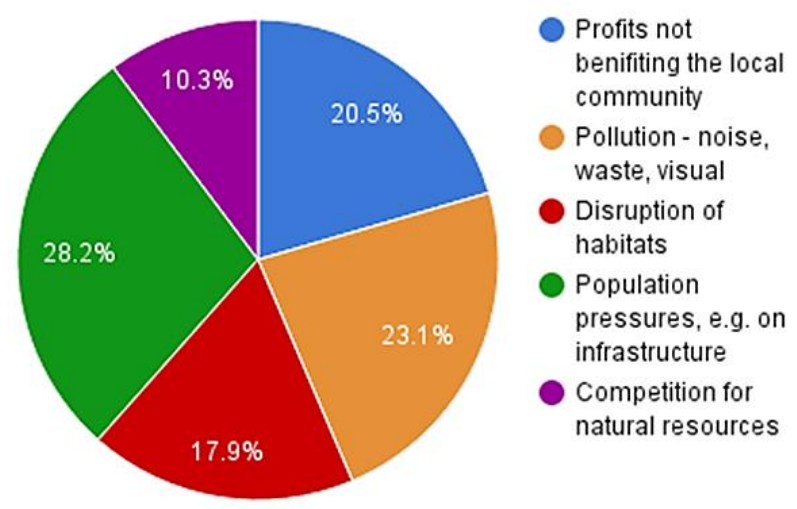

Dijagram 2. Stavovi i mišljenja ispitanika o negativnom uticaju ekoturizma

Graph 2. Respondents' views and opinions on the negative impact of ecotourism.

Izvor / Source: Globalecotourism 1, 2016

Prema istom izvoru (Globalecotourism1, 2016), manje od polovine (43\%) učesnika je prvo mislilo da ekoturizam ipak ima više pozitivnih, nego negativnih efekata. Nakon upoznavanja sa web stranicama koje promovišu ekoturizam, među učesnicima istraživanja došlo je do značajne promene u stavovima o ekoturizmu. Nakon upoznavanja sa principima ekoturizma, $97,1 \%$ učesnika je imalo pozitivan stav o ekoturizmu. Učesnici su došli do stava da je ekoturizam pozitivan koncept u turizmu i da pruža značajno više pozitivnih nego negativnih efekata.

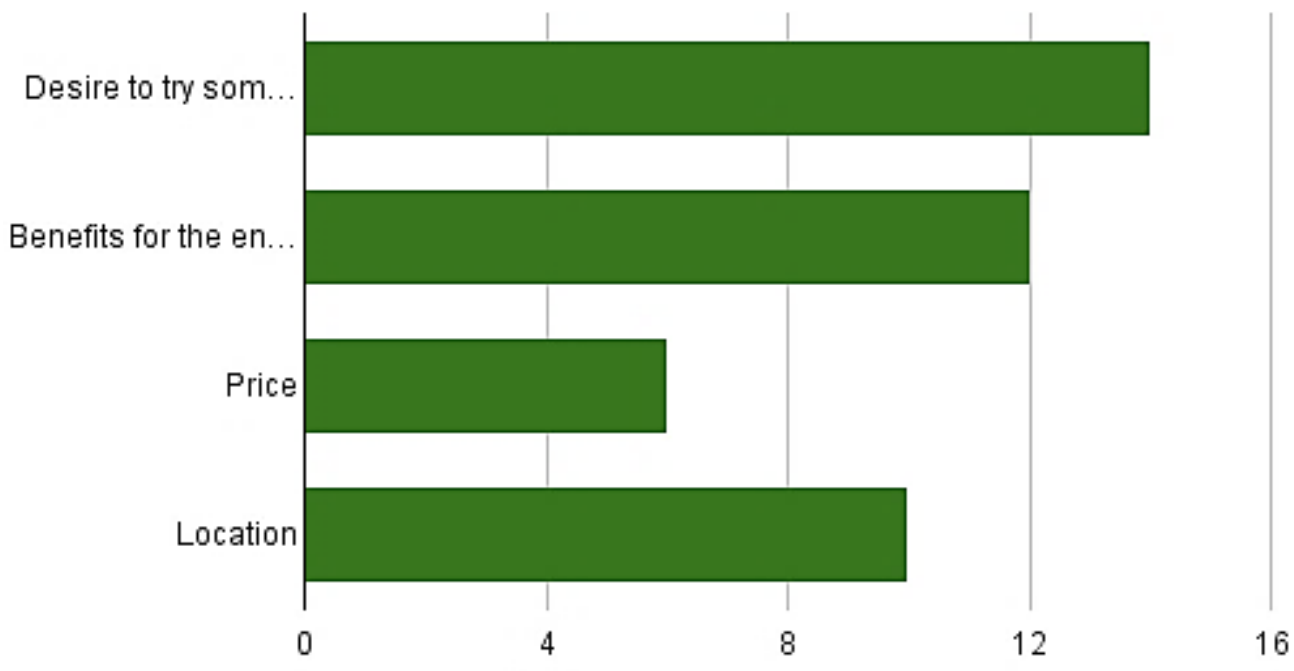

Number of participants

Dijagram 3. Motivi ispitanika o potencijalnom odlasku na eko-turistički odmor Graph 3. Respondents' motives for potential eco-tourist holiday. Izvor / Source: Globalecotourism 1, 2016 
Dijagram 3 pokazuje šta ispitanici veruju da bi ih motivisalo da idu na neki budući eko-turistički odmor. Kao glavni motiv za ekoturizam na malom uzorku od šesnaest ispitanika (eng. participants) navedeno je:

- Želja da se isproba nešto novo (Desire to try something new) - za to se izjasnilo 14 ispitanika.

- Koristi za zaštitu prirodne sredine (Benefits for the enviroment protection), izjasnilo se 12 ispitanika.

- Cenu boravka kao odgovor je navelo 6 ispitanika. Cena je navedena kao manje značajna stavka, što treba da bude dobar signal turističkim agencijama u kreiranju ponude.

- Lokaciju kao motiv za ekoturizam navelo je 10 ispitanika.

Uzorak navedenog istraživanja je jako mali i nije čak ni prigodan. Zato su interesantni podaci koje je objavila svetski poznata organizacija Booking.com koja posluje preko svog web portala. Booking.com je poznati globalni web portal za rezervisanje smeštaja na turističkim destinacijama. Svake godine za redom, daje izveštaje o kretanjima na turističkom tržištu. U svom izveštaju (Booking.com, 2018) navodi da svest o mogućnostima ekološkog smeštaja na turističkim putovanjima, raste iz godine u godinu. Interesovanje postoji čak i kada ovaj vid boravka ima veće troškove. U izveštaju se navodi da velika većina putnika, njih $87 \%$ želi da putuje održivo. Da je do sada $39 \%$ putnika uspevalo to i da ostvari, na svojim prethodnim putovanjima. Jedan od razloga za eko-putovanje, kako je navelo $40 \%$ ispitanika, jeste želja da se smanji negativan uticaj na životnu sredinu. 34\% ispitanika u istraživanju je navelo, da su već imala zanimljiva lokalna iskustva. $33 \%$ ispitanika je navelo, da želi da se oseća dobro, zbog adekvatnog izbora ekološki prihvatljivog smeštaja. Oko dve trećine ispitanika (njih 68\%) je prema (Booking.com, 2018) tokom 2018. god. navelo da namerava da boravi u ekološkom smeštaju. Ovaj procenat predstavlja određeni manji rast u odnosu na prethodne godine.

\subsection{Uticaj pandemije COVID-19 na ekoturizam / Impact of the COVID-19 pandemic on ecotourism}

2020. godina je, zbog pandemije COVID-19, bila značajno drugačija od svih proteklih (Center for Responsible Travel - CREST, 2020; Radić i dr., 2020). Prosperitet turizma koji je zabeležen tokom niza prethodnih godina, do pojave pandemije, potpuno je nestao. Tokom 2019. g. turizam je prosečno globalno zapošljavao 1 od $10 \%$ radnih mesta, u zavisnosti od zemlje do zemlje, s prosečnim učešćem turizma, kao industrije u globalnom BDP od $10 \%$. Prema podacima iz jula meseca 2020. g. (Center for Responsible Travel - CREST, 2020) u jeku turističke sezone, usled pandemije i raznih restriktivnih mera broj turističkih putovanja u svetu zabeležilo je pad od $58 \%$ do $78 \%$ u odnosu na prethodnu godinu. Ovakav pad dolazaka ugrozio je na globalnom nivou od 100 do 200 miliona radnih mesta. Procena je da je samo turizam uticao na smanjenje globalnog bruto društvenog proizvoda (BDP) u proseku od 2,7 do 5,5 hiljada milijardi USA \$. Kao posledica ovakvog pada prometa turističke industrije, neophodno je uvođenje radikalnih promena, nakon okončanja pandemije. $U$ istom izveštaju je navedena procena, da će biti potrebne desetine godina da se svetska turistička industrija oporavi od ove krize izazvane pandemijom COVID-19. Vlade mnogih zemalja pripremaju značajnu podršku strukturnom oporavku i daljem razvoju turizma nakon prestanka pandemije i ograničavanja kretanja ljudi.

Ostaje i dalje nepoznanica koliko će mere suzbijanja pandemije dati efekta, od čega direktno zavisi i vreme početka privrednog oporavka i vraćanje na stanje od pre izbijanja pandemije 2019. g. Iz navedenog razloga postoje više predviđanja zasnovanih na različitim scenarijima oporavka globalne ekonomije.

Drugi izvor u svom izveštaju (Alied Market Research - AMR n.d.) navodi da je uticaj pandemije Covida 19 ostavila možda najveći negativan globalni uticaj baš na turističku industriju u odnosu na sve ostale privredne grane. Očekuje se da će doći do stabilizacije i oporavka turizma, nakon pandemije do 2023. god., što iz sadašnje perspektive razvoja pandemije izgleda malo verovatno.

Jedno od predviđanja odnosi se na period od 2020. do 2025. g. Marketquest.biz n.d. navodi nešto skromniju složenu stopu rasta prihoda (Compound annual growth rate - CAGR) od turizma od $13,4 \%$. Prema njihovom predviđanju navedena stopa će dovesti do rasta globalnog tržišta ekoturizma sa 310.740 miliona US\$ pre krize 2019 g. do 514.010 miliona US\$ nakon oporavka do 2025. g.

Druga grupa autora (360 Market Updates n.d.) i (In 4Reserch n.d.) iznose svoja predviđana razvoja ekoturizma nakon pandemije. Po ovom izvoru do 2026. g. ekoturizam će dostići vrednost od 770.840 miliona US\$. To predstavlja značajan rast u odnosu na 2020. kriznu godinu, kada je ekoturizam imao vrednost tržišta od 351.000 miliona US\$.

Sa svoje strane, Market Intelligence Data n.d. u svom izveštaju navodi skromniju procenu rasta globalnog tržišta ekoturizma. Po ovom izvoru 2025. g. ekoturizam će u svetu dostići vrednost od 508.580 miliona US\$. Složena stopa rasta prihoda (CAGR) se predviđa da bude $14,9 \%$ do 2025 . g., da bi se dostigao navedeni rast tržišta.

Nešto skromniju projekciju predviđanju rasta globalnog tržišta ekoturizma daje izveštaj (Alied Market Research - AMR n.d.) koji predviđa da će do 2027. g. dostići vrednost od 333,8 milijardi USA \$. U izveštaju se navodi da postoje brojni nedostaci koji usporavaju 
rast i razvoj ekoturizma. Kao nedostaci su navedeni nerazvijena infrastruktura (putna i saobraćajna mreža), loša informisanost o smeštajni kapacitetima, nedostatak kvalitetnih higijenski prihvatljivih restorana, prodavnica hrane, kako u nerazvijenim tako i u razvijenim zemljama.

\section{ZAKLJUČAK / CONCLUSION}

Fokus turista koji podržavaju koncept održivog razvoja prenosi se i na njihovo interesovanje za ekološki turizam (ili ekoturizam). Ekološki turizam posmatra svoje destinacije kao okruženje u širem kontekstu koje čine ne samo prirodna sredina već $\mathrm{i}$ lokalna zajednica koja tu živi sa svim svojim autentičnostima. Ekološki turizam ima za cilj, da kroz sticanje ličnih iskustava, ostvari povezivanje turista sa prirodom i lokalnim autohtonom zajednicama na destinacijama. To je na izvestan način susret više civilizacija na jednom mestu.

Od ekoturizma se očekuje da turistima obezbedi jedinstvena iskustva i zadovoljstva prirodnim lepotama i različitostima kultura naroda na lokalitetu. Jedinstvena iskustva treba da se ostvare od aktivnosti u prirodi, prirodnih lepota, istorije, lokalne kuhinje do kulturoloških vrednosti stanovništva na destinacijama. Pri tome je predlog da što više vremena turisti provode u prirodnom okruženju na destinaciji ne ostavljajući za sobom smeće ili negativan uticaj na prirodu i biodiverzitet, razvijajući pri tome svest po pitanju dugoročne održivosti ovakve simbioze prirodnih lepota i lokalnog stanovništva. Razvoj ekološkog turizma traži što manji uticaj na zatečeno stanje okruženja, bilo da se radi o prirodnom okruženju ili životu u lokalnoj zajednici. Od turističkih organizacija se traži, da se uklope u način života ljudi i njihovog okruženja, ostavljajući minimalne negativne uticaje turista na ekodestinacije.

Zbog siromaštva i broja turista, lokalna zajednica je u opasnosti od nekontrolisanih uticaja na ekosisteme koja mogu negativno uticati na promene životne sredine. Boravak u prirodi i upoznavanje raznovrsnosti prirodnog sveta i bogatstva kulturno-istorijskog nasleđa na distinaciji upravo je glavni deo iskustva koje turisti žele da ponesu sa sobom. Ekoturizam ima za cilj da radi na povećanju ekološke i kulturne svesti da turisti i domaćini ostvare dugoročnu dobrobit i pozitivna iskustva.

$U$ istraživanju je oko polovina ispitanika navela da nije čula za ekoturizam. Kad su u pitanju efekti koje donosi ekoturizam na lokalne destinacije, ispitanici smatraju da je najveći pozitivan efekat očuvanje prirodne sredine. Ostali pozitivni efekti, kao što su ekonomski efekti, podizanje nivoa obrazovanja, i povećanje mogućnosti pojedinih lokalnih zajednica zastupljeni su približno podjednako. Kao najznačajniji negativni efekti navedeni su pritisak velikog broja turista na lokalnu infrastrukturu, zagađenje i buka ali i činjenica da ostvarena dobit ne pruža dovoljno koristi lokalnoj zajednici.

Tokom istraživanja manje od polovine ispitanika je prvo navelo da smatra da ekoturizam ima više pozitivnih nego negativnih efekata na lokalne destinacije. Nakon upoznavanja s informacijama o ekoturizmu sa sajtova skoro svi ispitanici su naveli da ekoturizam ima više pozitivnih nego negativnih efekata na destinacije. Kao glavni motiv za ekoturizam navedena je želja da se isproba nešto novo.

Promena stavova, edukacija, praćenje i podizanje ekološke svesti je neophodna aktivnost primene principa ekoturizma. Pravilnom primenom principa ekoturizma treba pronaći dugoročna rešenja koja pružaju ekonomske podsticaje za očuvanje biološke i kulturološke raznolikosti destinacija, s ciljem da se zaštiti prirodno i kulturno nasleđe destinacija koje turisti posećuju. Razvoj ekoturizma treba da doprinese povećanju mogućnosti, osposobljenosti lokalne zajednice da principe održivog razvoja sprovodi na pravi način. Time treba da se osnaže lokalne zajednice da čuvaju svoje prirodno i kulturološko nasleđe sa jedne strane a sa druge strane da kroz finansijske koristi od ekoturizma smanje siromaštvo. Smanjenje siromaštva na destinacijama predstavlja meru odvraćanja od migracije lokalnog stanovništva ka urbanim sredinama.

Ekoturizam smatra da odgovornost za sprovođenje navedenih principa treba da se deli kako na goste tako i na lokalno stanovništvo (i njihovu zajednicu). Odgovorno ponašanje treba da bude sprovedeno svih strana uključujući i javni sektor koji ovakav vid turizma treba da podrži u sprovođenju.

Veliki deo odgovornosti za razvoj principa ekoturizma prebacuje se na same turiste. Stav je da nije bitno gde se turisti nalaze u prirodi, već je bitno kako se turisti ponašaju dok su tamo. Svojim izborom ekodestinacija i turističke ponude, turisti praktično finansijski podržavaju napore razvoja ekoturizma. Zato je bitno dobro birati turističke ponude, koje ovu vrstu turizma zaista sprovode. Iz perspektive gostiju ekoturizam treba da doprinese razvoju ekološke svesti, boljem razumevanju i tumačenju različitih kultura i navika stanovništva na lokalitetu. Pri tome treba ostavljati što manji negativni uticaj na prirodu i tradicionalan način života lokalnog stanovništva.

Sa stanovišta lokalnih zajednica treba sprovesti mere dobre prakse koje će realizovati principe ekoturizma. Upotreba obučenih lokalnih vodiča predstavlja jedan deo dobre praksu. Agencije sa svojim lokalnim vodičima treba da doprinesu: bezbednosti boravka turista, boljem sticanju iskustava o ekodestinaciji, da u cilju informisanja turista skreću pažnju na vrednosti koje treba upoznati ali i da brinu o štetnim aktivnostima na turističkim destinacijama. U mnogim zemljama je zakonska obaveza stranih turističkih agencija da angažuju lokalne turističke agencije i vodiče, koji 
moraju biti prisutni tokom boravka gostiju. Bez angažovanja lokalnih agencija i vodiča, nije moguće organizovati turističke ture. Kazne za kršenje zakona za ovu vrstu prekršaja su vrlo ozbiljne.

Globalna pandemija COVID-19 dovela je do mera koje su podrazumevale i ograničavanja kretanja ljudi. Došlo je do mnogih poremećaja u svakodnevnom načinu funkcionisanja velikog dela ljudske populacije. Došlo je do smanjivanja ekonomske aktivnosti od kojih je turizam doživeo možda najveće negativne posledice. U zavisnosti od procene prestanka pandemije, pravljene su procene i predviđanja daljeg oporavka i razvoja globalnog ekoturizma. Iz sadašnje perspektive, teško je proceniti dalji razvoj pandemije na ljudsku populaciju. Zbog dobrobiti po oporavak zdravlja koji pruža ekoturizam ljudima, predviđa se ponovni uspon ekoturizma nakon prestanka pandemije. Očekuje se uvođenje novih radikalnih mera vlada širom sveta, koje treba da podrže strukturni razvoj turizma, gde ekoturizam treba da zauzme značajno mesto.

\section{LITERATURA / REFERENCES}

[1] 360 Market Updates. n.d. GlobalL Ecotourism Market Report, History and Forecast 2015-2026. Breakdown Data by Comapanies, Key Regions, Types and Application. https://www.360market updates.com/global-ecotourism-market16112051. Poslednji pristup January 25, 2021.

[2] Alied Market Research - AMR, n.d. Ecotourism Market by Traveler Type (Solo and Group), Age Group (Generation X, Generation Y and Generation Z), and Sales Channel (Travel Agents and Direct): Global Opportunity Analysis and Industry Forecast, 2021-2027. https://www.alliedmarket research.com/eco-tourism-market-A06364. Poslednji pristup January 18, 2021.

[3] Bhuiyan, A.H., Siwar, C., Ismail, S.M., Islam, R. (2012). The role of ecotourısm for sustaınable development in east coast economic region (Ecer), Malaysia, OIDA International Journal of Sustainable Development, 3 (9), 53-60.

[4] Booking.com. (2019). Booking.com reveals key findings from its 2019 sustainable travel report. https://globalnews.booking.com/bookingcomreveals-key-findings-from-its-2019-sustainabletravel-report. Poslednji pristup January 21, 2021.

[5] Booking.com. (2018). Where Sustainable Travel is Headed in 2018. https://globalnews.Booking. $\mathrm{com} /$ where-sustainable-travel-is-headed-in2018/. Poslednji pristup January 21, 2021.

[6] Center for Responsible Travel - CREST. (2020). Case for Responsible Travel: Trends \& Statistics 2020. https://www.responsibletravel.org/docs/ CaseforResponsibleTravel_2020_Web.pdf. Poslednji pristup January $\overline{19}, 2021$.
[7] Globalecotourism1. (2016). Public Perceptions of Ecotourism: Eco-tourism or Eco-exploitation?, https://sites.google.com/site/globalecotourism1/ public-perceptions-of-ecotourism. Poslednji pristup November 19, 2021.

[8] In 4Reserch. n.d. Ecotourism Market - Strategic Recommendations, Trends, Segmentation, Use Case Analysis, Competitive Intelligence, Global And Regional Forecast To 2026. In 4Reserch. Poslednji pristup January 25, 2021.

[9] Janković, M., Ivannikov, N., Jovanović, L., Gajdobranski, A. (2020). Doprinos zelene ekonomije razvoju ekoturizma i organskoj proizvodnji. Ecologica, 27(98), 217-223.

[10] Kumar, M. (2020). What's the difference between green tourism, ecotourism, and sustainable tourism? https://medium.com/colandian/whats-thedifference-between-green-tourism-ecotourismand-sustainable-tourism-af4d0a4d8db8. Poslednji pristup January 13, 2021.

[11] Market Intelligence Data. n.d. Global Ecotourism Market Growth (Status And Outlook) (2020-2025). https://www.marketintelligencedata.com/reports/ 133512/global-ecotourism-market-growth-statusand-outlook-2020-2025. Poslednji pristup January 25, 2021.

[12] Marketquest.biz. n.d. https://www.marketquest.biz/report/32579/global -ecotourism-market-2020-by-company-regionstype-and-application-forecast-to-2025. Poslednji pristup January 25, 2021.

[13] Mladenović, M., Bojičić, R. (2020). Razvoj ekoturizma u opštini Štrpce - mogućnosti i perspektive. Ecologica, 27(98), 232-239.

[14] Radić, V., Radić, N. Ravić, N. (2020). Uticaj pandemije korona virusa na ciljeve održivog razvoja i ekonomiju. Ecologica, 27(99), 366-375.

[15] Strasdas, W. (2001). Ökotourismus in der Praxis: Zur Umsetzung der sozio-ökonomischen und naturschutzpolitischen Ziele eines anspruchsvollen Tourismuskonzeptes in Entwicklungsländern. Diss., Techn. Univ. Berlin 2000.

[16] The Interenational Ecotourism Society - TIES. n.d. What Is Ecotourism? https://ecotourism.org/what-is-ecotourism/. Poslednji pristup January 13, 2021.

[17] United Nations World Tourism Organization UNWTO. n.d. Sulorcid.org/staninable development. https://www.unwto.org/sustainable-development. Poslednji pristup January 14, 2021.

[18] World Tourism Organization International Network of Sustainable Tourism Observatories INSTO, n.d. http://insto.unwto.org/. Poslednji pristup January 14, 2021. 